\title{
THE EFFECTS OF SERVICE QUALITY, CUSTOMER SATISFACTION, TRUST, AND PERCEIVED VALUE TOWARDS CUSTOMER LOYALTY
}

\author{
Tanisah ${ }^{\bowtie}$, Ida maftuhah ${ }^{\bowtie}$ \\ Fakulty of Economics, Universitas Negeri Semarang, Semarang, Indonesia
}

\begin{tabular}{l} 
Info Artikel \\
\hline Sejarah Artikel: \\
Diterima Januari 2015 \\
Disetujui Februari 2015 \\
Dipublikasikan Maret 2015 \\
\hline Keywords: \\
Service Quality; \\
Customer Satisfaction; \\
Trust; \\
Perceived Value; \\
Customers' Loyalty
\end{tabular}

\begin{abstract}
This purpose of the research is to examine the effects of service quality, customer satisfaction, trust, and perceived value towards customer loyalty in KJKS BMT Bondho Tumoto Semarang. The sample was taken by using incidental sampling techniques and it had 98 customers. The data was analyzed by multiple linier regressions. Test results in partial show that service quality, trust and perceived value gave positive and significant effect towards customers' loyalty. In contrast, customer satisfaction did not have significant effect towards customers' loyalty. Then, simultaneous testing show that service quality, customer satisfaction, trust and perceived value gave significant effects towards customers' loyalty. This study found that from those variables, trust variable gave the biggest effect towards customers' loyalty.
\end{abstract}

\section{PENGARUH KUALITAS PELAYANAN, KEPUASAN, KEPERCAYAAN, DAN PERCEIVED VALUE TERHADAP LOYALITAS NASABAH}

\begin{abstract}
Abstrak
Tujuan dari penelitian ini adalah mengetahui pengaruh dari kualitas layanan, kepuasan pelanggan, kepercayaan, dan persepsi nilai (perceived value) terhadap loyalitas pelanggan di KJKS BMT Bondha Tumoto Semarang. Penelitian ini menggunakan teknik incidental sampling dengan 98 pelanggan. Data penelitian ini dianalisis dengan menggunakan regresi linier berganda. Hasil analisis uji parsial menunjukkan bahwa kualitas layanan, kepercayaan dan perceived value secara signifikan berpengaruh positif terhadap loyalitas pelanggan. Sebaliknya, kepuasan pelanggan tidak berpengaruh signifikan terhadap loyalitas pelanggan. Berdasarkan uji simultan, kualitas layanan, kepuasan pelanggan, kepercayaan dan perceived value berpengaruh secara signifikan terhadap loyalitas pelanggan. Penelitian ini menemukan bahwa berdasarkan variable-variabel tersebut, variable kepercayaan memberikan pengaruh terbesar terhadap loyalitas pelanggan.
\end{abstract}

JEL Classification: M3, M31

\footnotetext{
$\triangle$ Alamat korespondensi :

Gedung C6 Lantai 1 Fakultas Ekomoni Universitas Negeri Semarang

Kampus Sekaran, Gunungpati, Semarang

Jl. Taman Siswa, Sekaran, Gunungpati,Semarang

E-mail: aniskanza@yahoo.com; idaf123@yahoo.com
} 


\section{INTRODUCTION}

Recent business development has been influenced by intensifying competition. That condition causes business people compete each other to face it and gain competitive advantages (Ellena, 2011). Nowadays, business engaged in service tries to improve the service quality. Companies try to build close relationship with customers so they become loyal. According to Ellena (2011), Yulianto (2010), Rintar (2011) having loyal customers is the ultimate goal of company because customers can ensure company's continuation for long term. Geok in Setiawan and Ukudi (2007), Loyalty can have big advantages for the company because it influences customers' buying pattern and free recommendation to other people. Customer loyalty is not easily formed without its influencing factors.

Many researchers have ideas that service quality, customer satisfaction, trust and perceived value have effects towards customers' loyalty. However, there is some discrepancy in previous researchers. Akbar and Parvez (2009) research with variable of service quality and trust, it showed that variable of service and trust gave positive and significant effects towards loyalty.

While the research done by Thakur and Singh (2011) with the same variables, service quality and trust shows different results. Variable of service quality and trust did not have positive and significant effects towards loyalty. Research by Susanto and Mangatus (2010) with variable of trust, customer satisfaction and perceived value showed that variable of customer satisfaction and perceived values gave positive effects towards loyalty.
In contrast to the research by Chen and Tsai (2008) with three variables (perceived value, satisfaction, and loyalty) showed that perceived value gave positive and significant effects towards loyalty whereas variable of satisfaction did not have significant effect towards loyalty.

Different results are found in Yee and Faziharudean's research (2010) with variables of service quality, perceived value, and customer loyalty. It showed that variable of service quality and perceived value did not have positive and significant effects towards loyalty.

Based on the different results from some researchers, it can be concluded that there is no consistency in the result of previous researchers so it there is research gap about the effect of some variables (service quality, customer satisfaction, trust and perceived value) towards loyalty.

In an effort to improve customers' loyalty, BMT Bondho Tumoto through the vision and mission, improving economic power of people through awareness to do transaction by sharia tries to have the best service to the customers by giving revolving fund for low socioeconomic customers each year that collaborate with Financing Agency of Revolving Fund or LPDB (Lembaga Pembiayaan Dana Bergulir) Semarang City, providing clean room and has Air Conditioner (AC) and waiting room provided by $\mathrm{TV}$, giving loan service for small and medium entrepreneurs with small interest rate, implementing pick the customer to ease them who wants to save or draw the money.

Based on Table 1 from BMT Bondho Tumoto, total customer who closed the account increases in recent each six year

Table 1. Total customers who closed the account in KJKS BMT Bondho Tumoto Semarang directly or indirectly (Year of 2009 - 2014)

\begin{tabular}{ccccccc}
\hline Type of saving & $\mathbf{2 0 0 9}$ & $\mathbf{2 0 1 0}$ & $\mathbf{2 0 1 1}$ & $\mathbf{2 0 1 2}$ & $\mathbf{2 0 1 3}$ & $\mathbf{2 0 1 4}$ \\
\hline Voluntary saving & 15 people & 25 people & 30 people & 49 people & 71 people & 98 people \\
Time deposit & 11 people & 9 people & 12 people & 12 people & 18 people & 26 people \\
\hline
\end{tabular}

Source: data processed (2014) 
Tanisah \& Ida Maftuhah / The Effects Of Service Quality, Customer ...

(2009-2014). It indicates that customer loyalty to have an account in KJKS BMT Bondho Tumoto Semarang is still low. Recognizing that phenomena, researchers are interested in discussing the topic and made the title of research is "The Effects of Service Quality, Customer Satisfaction, Trust and Perceived Value towards Customer loyalty in KJKS BMT Bondho Tumoto Semarang”.

\section{Customer Loyalty}

Oliver (1999) professed the view that customer loyalty as a deep commitment by the customer to re-purchase or re-buy service and product from one particular firm or agency in the future, even if there are influences from situation and marketing efforts potentially causes shift of behavior.

Thakur and Singh (2012) expressed that customer loyalty is highlight by the combination of attitudes (intention to buy again and/or buy additional products or services from the same company, willingness to recommend the company to others, commitment to the company demonstrated by a resistance to switching to a competitor) and behaviors (repeat purchasing, purchasing more and different products or services from the same company, recommending the company to others)

While Griffin (2005) explained that loyalty may be defined as a buying behavior. Loyal customer is people who do regular purchasing, buy interlined product and service, have recommendation to others, and show immunity towards competitor. Parasuraman et al. (1988) declared that service quality is therefore viewed as the degree and direction of discrepancy between consumers' perceptions and expectation.

Zeithaml et al. (1996) defined that service quality is how far the service can fulfill needs or customer expectation. Setiawan and Ukudi, (2007) stated that service quality is a whole customer impression to inferiority/superiority of argumentation and serviced offered. Parasuraman et al. (1988) remarked that on 22 items considered by customer in considering service quality. Those items are categorized into five, they are: Tangible, Reliability, Responsiveness, Assurance, Empathy

\section{Customer Satisfaction}

Rangkuty (2006) defined the customer satisfaction is as a customer responses towards discrepancy between the previous need and actual performance felt after using. Barnes (2003) stated that satisfaction is customer responses for meeting the need. It means that customer judgment for the service and goods gives pleasure related to need fulfillment, including inappropriate of need fulfillment or exceed expectation of need fulfillment.

According to Kotler (2006), satisfaction as “a person's feeling of pleasure or disappointment resulting from comparing product perceived performance (or outcome) in relation to his or her expectations" If performance is under expectation, customer will be disappointed. If performance meets expectation, customer will be satisfied. If performance is exceeding expectation, customer will be so satisfied or happy.

\section{Trust}

Mayer et al. (2007) defined trust as a willingness of a party to be vulnerable to the actions of another party based on the expectation that the other will perform a particular action important to the trustor, irrespective of the ability to monitor or control that other party. According to Mowen and Minor (2002), consumer trust is consumer knowledge about an object, its attributes and its benefits, is based on the cognitive learning process

Barnes (2001) declared trust is conviction that someone will get what he wants from other, not what he is afraid of. Trust is related to willingness to have certain behavior because the partner will give what is expected 
and an expectation is generally owned by party who the words, promises or statements are trustworthy.

\section{Perceived Value}

Rangkuty (2006) defined value as an overall assessment on benefits of certain products based on customer perception of what have been received and given by the products. Holbrook in (Tjiptono, 2006) defined value as an "experience of interactive and relativistic preference" about subject experience in doing interaction with certain object. In the context of customer value, the subject is customer while relevant object is products (goods, service, people/private, place, ideas, event/activity, and organization).

Pollack in (Rahmayanty, 2013) stated that service quality consisting of 5 dimension, tangible, reliability, responsiveness, assurance and empathy can build customer loyalty to service supplier. Based on that, loyalty are able to create quality in every service.

$\mathrm{H} 1$ : There is a positive and significant relationship between service quality and customer loyalty.

Hendrawan (2013) described that customer satisfaction is related to customer loyalty, a satisfied customer will be a loyal customer. A loyal customer will be as a "great marketing assets" for company by giving positive information and recommendation to other prospective customer.

$\mathrm{H} 2$ : there is a positive and significant relationship between customer satisfaction and loyalty.

Moorman et al. (1993) reported that "without any trust, a relationship will not stand for a long time. Getting customer satisfaction and trust will gain customer loyalty for long term."

H3: there is a positive and significant relationship between trust and customer loyalty.
According to Yee and Faziharudean (2010) perceived value or accepted value has contribution to customer loyalty.

$\mathrm{H} 4$ : there is a positive and significant relationship between perceived value and customer loyalty.

H5: there is a positive and significant relationship simultaneously among service quality, customer satisfaction, trust and perceived value.

\section{METHOD}

Population in this research is all customers (5148 customers) in KJKS BMT Bondho Tumoto Semarang. Sample in this research is 98 respondents through Slovin's formula. Incidental sampling was used as techniques of data collection referring to Sugiyono (2010). Criteria in the sample collection were respondents with minimum one year period as a customer. Variable descriptive analysis and multiple linier regression analysis were used as a technique of data collection.

\section{RESULTS AND DISCUSSION}

Based on the hypothesis testing results towards variable of service quality, it was gained is 2.618 , which indicates positive with level of significance is $0,010<0,05$ indicates significant. In other word, service quality has positive and significant effects towards customer loyalty. Therefore, H1 that shows service quality having positive and significant effects towards customer loyalty is accepted. This research supports Akbar and Parvez's (2001) finding stating that service quality has positive and significant effects towards loyalty.

The result is supported by the highest average score in assurance indicator (78.4\%). It indicates that company's effort in giving assurance and employees' knowledge of information haven has good impression for customer. Besides, it is supported by reliability indicator which gained average score $67,6 \%$. 
That score indicates that customer impression towards employees' performance in giving greeting for each coming customer is good and service time informed is always on time based the schedule. While, aspect of empathy got average score $57,4 \%$. That score indicates that customer impression towards empathy and attention haven by employees is good.

Next, the hypothesis testing results towards variable of satisfaction, it was gained is 471 , which indicates positive with level of significance is $0,639>0,05$ indicates insignificant. In other words, satisfaction has positive and insignificant towards customer loyalty. Hence, $\mathrm{H} 2$ that shows satisfaction having positive and significant effects towards customer loyalty is rejected. It means that if customer satisfaction increases, it will not influence loyalty increasing. This result supports Chen and Tsai's (2008) finding stating that variable of satisfaction has positive and insignificant effects towards loyalty.

The result is supported by the average score in indicator of customer overal satisfaction (55.4\%) that is included in moderate criteria. It indicates that company has not been ready for customer. The lowest average score have not been able to give maximal satisfaction to customers. The lowest average score is also gained from expectation indicator $(49,6 \%)$ that is included in low criteria. It indicates that company has not been good at effort of fulfilling customer's expectation.

The hypothesis testing result in variable of trust gained of 3.115, which is positive, with level of significance is $0,002<0,05$ indicates significant. In other words trust has positive and significant effects towards customer loyalty. Hence $\mathrm{H} 3$ that shows trust having positive and significant effect toward customer loyalty is accepted. This research supports finding Akbar and Parvez's (2009) and Yee and Faziharudean (2010). It found that trust has positive and significant effects towards loyalty.

The result is supported by the highest average score in integrity indicator (72.2\%). It indicates that customer impression towards company's reputation is good and company in actualizing the promises given is good. Aspect of benevolence got average score of respondents' answer is $56.7 \%$. It indicates that there are many customers believes that the employees have good act for the sake of customer and moral value given by the employees has good impression for customer.

Next, testing hypothesis towards variable of perceived value, it was gained is 2.502 with level of significance is $0,014<0,05$ indicates significant. In other words, perceived value has significant effects towards customer loyalty. Hence, $\mathrm{H} 4$ that shows perceived value having positive and significant effects towards customer loyalty is accepted. The result supports Chen and Tsai' (2008), Susanto and Mangatus's (2010) finding declaring that perceived value has positive and significant effects towards loyalty.

The result is supported by the highest average score, that is in indicator of value is 65 , $2 \%$. It indicates that company in implementing sharia principles in the performance is good, the ease in administration process has good customer impression, and production sharing or implemented interest is good for customer.

Based on simultaneous testing result or $\mathrm{H} 5$, it is known that $\mathrm{F}_{\text {count }}$ is greater than $\mathrm{F}$ table $(5,224>2,000)$ and level of significance is 0,001 which means it is smaller than $(\alpha)=0,05$. From that testing result, it can be concluded fan $\mathrm{HO}$ is rejected and $\mathrm{Ha}$ is accepted. It means that service quality, satisfaction, trust and perceived value simultaneously have positive and significant effects towards customer loyalty.

\section{CONCLUSION}

Based on the results and discussion previously described, it can be concluded as follows: First, service quality has positive and significant effects towards customer' loyalty of KJKS BMT Bondho Tumoto Semarang. It means that by improving a good service quality, it can increase customers' loyalty. Therefore, creating a loyalty needs having a good service quality because pros and cons of the service 
had by company have good effects towards long term sustainable relationship between company and customers. Hence, it can influence the customers' loyalty.

Second, customers' satisfaction has positive and insignificant effects towards customerloyalty in KJKS BMT Bondho Tumoto Semarang. It means that if company successfully has high satisfaction to the customers, it will not have effect towards customers' loyalty. Third, tust has positive and significant effects towards customer loyalty in KJKS BMT Bondho Tumoto Semarang. It means that, if customers' trust is increased, customer loyalty will increase. Therefore, trust factor is really important to be kept by the company. More, considering Business Company of financial service is a trust business. Having the trust, customers will feel in safe keeping their assets. It makes them being loyal to the company.

Fourth, perceived value has positive and significant effect towards customer loyalty in KJKS BMT Bondho Tumoto Semarang. It means that, if perceived value or value accepted by customer is good, it will increase customer loyalty. Therefore, perceived value or value accepted by customer is also important as a concern because if customer gets better feedback from company, customer loyalty will increase.

Based on those conclusion, there are some advises for some related parties. First, company should keep and maintain better service quality in the future. This effort can be done by keeping some important service efforts for the customers, such as providing the facilities and more spacious waiting room and implement queueing system so waiting customer is well ordered.

Second, company should consider the importance of customer satisfaction even the research's results did not have significant effects towards loyalty in order to customer feels happy and stand using service given by company. Third, company should always keep and maintain better trust in the future because in financial service business, trust is the main thing considered by customer.
Fourth, company should improve the perceived value or value accepted by customer. Fifth, company should improve better perceived value or value accepted by customer because it has a big impact in financial business. Therefore, it is better that employees are given instruction about how to deliver information in right and proper way to the customers so they can easily get the information explained.

Sixth, researchers who interested in doing the same research are expected to observe and explore more about the problems in KJKS BMT Bondho Tumoto Semarang especially, and other object in general by adding other variables and different methodology in order to make the research more various.

\section{REFERENCES}

Akbar, M. M. \& Parvez, N. 2009. Impact of Service Quality, Trust, and Customer Satisfaction on Customer Loyalty. ABAC Journal. 29 (1):24-28.

Barnes, J. G. 2003. Secrets of Customer Relationship Management (Rahasia Manajemen Hubungan Pelanggan. Yogyakarta: Andi.

Chen, C-F \& M-H, Tsai. 2008. Perceived Value, Satisfaction, and Loyalty of TV Travel Product Shopping: Involvement as a Moderator. Journal of Tourism Management. 29:1166-1171.

Ellena, F. 2011. Analisis Pengaruh Kepercayaan, Komitmen, Komunikasi, dan Penanganan Keluhan Terhadap Loyalitas Nasabah (Studi pada nasabah PT.BRI (Persero) Tbk. Cabang Pemalang). Jurnal Fakultas Ekonomi, Semarang: Universitas Diponegoro.

Griffin, J. 2005. Menumbuhkan Customer Loyalty dan Mempertahankan Kesetiaan Pelanggan. Jakarta: Erlangga.

Hendrawan, B. 2013. Pengaruh Customer Satisfaction dan Corporate Image terhadap Customer Loyalty Provider "XL" di Surabaya. 1-4.

Kotler, P \& Keller, K. L. 2006. Manajemen Pemasaran. Edisi 12 jilid 1. PT indeks.

Mayer, R. C., Davis, J. H. \& Schoorman, F. D. 2007. An Integrative Model Of Organizational Trust: Past, Present, And Future. Academy of Management Review. 32 (2):344-354. 
Mowen, J. C \& Minor, M. 2002. Perilaku Konsumen. Jakarta: Erlangga.

Moorman, C., Deshpande, R \& Zaltman, G. 1993. Factors Affecting Trust in Market Research Relationships. Journal of Marketing. 57: 81-101.

Oliver, R. L. 1999. Whence Consumer Loyalty?. Journal of Marketing. 63: 33-44.

Parasuraman, A., Zeithaml, V. A \& L. Berry. 1988. A Multiple-Item Scale for Measuring Consumer Perceptions of Service Quality. Journal of Retailing. 64 (1): 12-40.

Rangkuti, F. 2006. Measuring Customer Satisfaction (Teknik Mengukur dan Strategi Meningkatkan Kepuasan Pelanggan Plus Analisis Kasus PLNJP). Jakarta: PT Gramedia Pustaka Utama.

Rintar. 2011. Analisis Hubungan Kualitas Jasa terhadap Kepuasan Konsumen pada Lembaga Pendidikan Kejuruan. Jurnal Dinamika Manajemen. 2(1)

Setiawan, M. B \& Ukudi. 2007. Pengaruh Kualitas Layanan, Kepercayaan, dan Komitmen terhadap Loyalitas Nasabah (Studi pada PD. BPR Bank Pasar Kendal). Jurnal Bisnis dan Ekonomi. 14 (2): 215-227.

Sudarma, K. 2013. Mencapai Sumber Daya Manusia Unggul (Analisis Kinerja dan
Kualitas Pelayanan). Sugiyono. 2010. Metode Penelitian Pendidikan (Pendekatan Kuantitatif, Kualitatifdan RéD). Bandung: Alfabeta.

Susanto, B. \& Mangatua, F. W. 2010. Pengaruh Trust, Customer Satisfaction, Perceived Value, dan Commitment terhadap Loyalitas Pelanggan Three. Jurnal Manajemen. 5 (1): 17-32.

Thakur, S \& Singh, A. P. 2012. Impact of Service Quality on Customer Satisfaction and Loyalty: In The Context of Retail Outlets In DB City Shopping Mall Bhopal. International Journal of Management Research and Review. 2: 334-344.

Tjiptono, F. 2006. Pemasaran Jasa. Malang: Bayumedia Publishing.

Yee, B. Y \& Faziharudean, T. M. 2010. Factors Affecting Customer Loyalty of Using Internet Banking in Malaysia. Journal of Electronic Banking Systems. 1-21.

Yulianto, A. 2010. Meningkatkan Kualitas Pelayanan Jasa Penerbangan Indonesia Paska Insiden Kecelakaan Pesawat Terbang. Jurnal Dinamika Manajemen. 1(1)

ZeithamI, V. A., Berry. L \& Parasuraman, A. 1996. The Behavioral Consequences of Service Quality. Journal of Marketing. 60: 31-46. 